\title{
An Ecocritical Reading of Selected Poems by Daniel Abdal-Hayy Moore
}

Taher Mabrouk Muhammad Al-abbasi

M.A Candidate, Faculty of Arts, Fayoum University 


\title{
An Ecocritical Reading of Selected Poems by Daniel Abdal-Hayy Moore
}

\author{
Taher Mabrouk Muhammad Al-abbasi \\ M.A Candidate, Faculty of Arts, Fayoum University
}

\begin{abstract}
:
The academic investigationabout the future of thenatural world has become common in the modern world. The existence of a coherent relationship between humanity and environment is essential for the survival of the humanity. Hence, the study of nature and environment has formed an important part of various academic studies. The study of the relationship between literature and environment is known as "ecocriticism".
\end{abstract}

This paperaimsat analyzing selected poems by Daniel Abdal-Hayy Moore, using the main concepts of ecocriticism as an analytical approach. The premise of the paper is based on the poet's view of nature and environment which comes from his Sufi background. An ecocritical reading of a selection of poems by Daniel Abdal-Hayy Moore reveals the effects of human actions on the natural landscape and the environment.

Reading Moore's poetry from an ecocritical point of view reflects the growing interest in the natural world and environment.Through elucidating the features of nature in the selected poems, we can view the respect of the natural world and the environmental awareness in Moore's poetry. 
In Western Sufi literature, ecocriticism as a tool of analysis is new. Thus, this study is motivated by Moore's poetry and attempts to examine to what extent ecocriticism can be used as an analytical lens for reading Sufi poetry about nature and environment.

Daniel Abdal-Hayy Moore (1940-2016) is an American poet who converted to Islam. He adopts the spiritual path of Islam which is Sufism.He is widely known as "American Islam's poet laureate of the English speaking Muslim community" (qtd. in Gana 1578). Moore wrote more than 25 poetic works, so the range of his poetry is wide.

The poetry of Daniel Abdal-Hayy Moore fosters aesthetics that provide the base for the theoretical field of ecocriticism, which focuses on the representations of nature in literature, and its engagement with the environment: plants, animals, landscapes, and natural resources. Ecocriticism is concerned with human interaction with the physical environment. It analyzes works of art which raise a moral questions about human behavior towards nature. The principal core of this critical approach is to examine how human interaction with the environment reflects the cultural and spiritual ethics.

Nature has always been an inseparable source of Moore's poetic expression. In his poems, Moore celebrates the beauty of 
nature in the finest possible way. Moreover, he is against human selfishness and instrumental attitude towards nature and laments human helplessness at the disastrous acts of nature. Khaled Mattawa reports: "His works are full of illusions to infinities, multitudes, and depths. He often ponders the stars and the cosmos and laments human desecration of the environment" (1592). According to Mattawa, Moore's poetry contains reference to the world of nature and denouncing to environmental degradation which are the two themes of ecocriticism.

Ecocriticism has transformed the academic study of literature, as it fundamentally develops a new literary agenda for the interpretation of literary texts. Cheryll Glotfelty states: "Ecocriticism is the study of the relationship between literature and physical environment" "Literary Studies in an Age of Environmental Crisis, XVIII". Therefore, ecocriticism has opened a space for critics to search for environment and nature in literary texts. In adopting ecocriticism, critics became very close to direct their attention to the environment and nature.

The concept of "ecocriticism" was first introduced in William Rueckert's 1978 essay "Literature and Ecology: An Experiment in Ecocriticism." This essay offers a great contribution in bringing the meaning of ecology and ecological 
concepts to the study of literature. He makes suggestions to apply ecology and ecological concepts to the study of literature. Reuckert defines ecocriticism in his essay as " the application of ecology and ecological concepts to the study of literature, because ecology has the greatest relevance to the present and future of the world we live." (107)

Preceding Reuckert's essay, Joseph Meeker's book The Comedy of Survival: Studies in Literary Ecology is considered a founding work for American ecocriticism. Meeker is a biologist who writes in the field of literature. He offers the first genuinely new reading of literature from an ecological viewpoint. He suggests the term 'literary ecology.' He defines it as "The study of biological themes and relationships which appear in literary works." (5)

However, the specific term ecocriticism became popular in 1991, when the Modern Language Association organized a meeting by Harold Fromm titled "Ecocriticism, the Greening of Literary Studies". In the next year, at the annual meeting of the Western literature Association, ecocritics formed the Association for the Study of Literature and Environment (ASLE), with Scott Slovic elected the first president. ASLE is the first organized association to study literature and the environment. 
It should be noticed that The Ecocriticism Reader: Landmarks in Literary Ecology(1996)byCheryll Glotfelty and Harold Fromm revived the ecocritical approach towards literary texts. This book is regarded as the first anthology to discuss the relationship between literature and environment. It is the source book for ecocriticism. In the introduction to this anthology, Glotfelty gives a preliminary definition of ecocriticism as:

What then is ecocriticism? Simply put, ecocriticism is the study of the relationship between literature and physical environment. Just as feminist criticism examines the language and literature from a gender consciousness perspective, and Marxist criticism brings an awareness of modes of production and economic class to its reading of a text, ecocriticism takes an earth centered approach to literary studies. (XVIII)

The above mentioned definition of ecocriticism focuses principally on the representation of physical environment and non-human nature in literary works. The presence of a bond between the human and the non-human forms the ecocritical basis of the text. Hence, ecocritical approaches ignore the social and linguistic structure of the text, and emphasize on the relationship between literary work and physical environment. 
Moreover, Glotfelty predicts in the introduction of her anthology book that ecocriticism in the future will be an interdisciplinary, multicultural, multiethnic and international set of approaches:

In the future... The interdisciplinary work is well underway and could be further facilitated by inviting experts from a wide range of disciplines to be guest speakers at literary conferences and by hosting more interdisciplinary conferences on environmental topics. (XXV)

This means that all sciences come together to analyze the environment and unfold solutions for the current environmental crisis. In this sense ecocriticism becomes interdisciplinary as it tries to look at the relationship between humans and environment from various view points; sociological, psychological, anthropological, theological, scientific and philosophical. Michael Cohen defines ecocriticism as an interdisciplinary approach as:

How does one become interdisciplinary? Because ecocriticism is interested in ecology and other environmental sciences, it must cross disciplinary boundaries and use the methods and findings of other disciplines when it asks "What is 
environment?" or "Why think in ecological or revolutionary ways about it?" (Blues in the Green: Ecocriticism under Critique 18)

Linking the religious discourse with the environmental agenda is an example of interdisciplinary approaches. Glotfelty identifies the theologians' attitudes towards the environment. "Theologians, too, are recognizing that, as one book is subtitled “The Environment Is a Religious Issue.” (XXII) Glotfelty refers to the Judeo-Christian theologians' attempt to explain the biblical viewpoints of the relationship between humans and environment.

The importance of religion in environmental studies is that religion can help humanity to better understand our relationship with the planet. It has a powerful force in our human life and our spiritual attitudes towards the earth. Researchers and researches ignore the Islamic view of environment. Therefore, it is important to refer to the Islamic view of nature and environment. The Islamic religious views of nature and environment is prominent in many scholarly writings about environment. One of these scholars is Seyyed Hossein Nasr. Nasr represents the Islamic Sufi views of natural world and environment. 
In his writings, Nasradvocates the idea that humans cannot live in harmony with nature without ritualizing their relationship with the natural world. Religion is so significant in understanding the solution for the environmental crisis for many reasons. Firstly, we live with environment at peace with religious virtues. Secondly, religious rituals are means of establishing cosmic harmony. Thirdly, religion has an authentic knowledge about human state and nature. (Religion and the environmental crisis 8)

Indeed, religion allows humans to recognize the spirituality in natureand to know that God is the originator of all creation. Consequently humans behave respectively with the nature and environment. Nasr indicates in a lecture at Birmingham University that:

The religious view of nature enables us to see the sacred in nature and therefore to treat it not only with respect but also as a part of our greater self. It teaches us how precious each being created by God is and how great as in to destroy wantonly any creature that by virtue of its existence bears the imprint of the Divine and its witness to the One who is our origin and end. (Religion and the Order of Nature 288) 
Thereligious view of nature promotes an awareness of the spiritual significance of nature. Wesee this in an example of Abdal-Hayy Moore's poetry regardingthe natural environment as a method of contemplating God's Omnipresence. Moore seeks spiritual connection with God through all things especially through nature. He sees a glimpse of the Creator in all His creation. Nature is a gift from God to human beings. One of Moore's poems in which he shows his readers the greatness of God -the Creator of nature- by comparing His creation to human inventions is 'Inventor':

Nefer Hotep invented the tweezers

but God invented the kidney

so who's the better inventor?

Johann Kirsten invented the thumbtack

but God invented the waterfall

so who's the better inventor?

Thomas Edison of course invented the light bulb among other things such as the

phonograph the motion picture the incandescent filament but God invented the wiggly antennae on ants so who's the better inventor?

A glass for seeing far in the distance 
but God invented the distance

A gyroscope for righting a ship's balance but God invented balance

The guillotine that severs head from trunk but God invented both head and trunk and intended them to go together.

(Invention of the Wheel 108)

The poet tries to find God through every parcel of nature. He contemplates nature as a reflection of God. Sufis consider nature as a sign of God's Creation and it guides them to a higher knowledge of their Creator. There are many beautiful creatures of God in this world, which have their own benefits for our life and they are obvious signs of the Omnipresence of God in our mundane world.

This poem creates an impression of the greatness of God's Creation by comparing His creation to human inventions. God is the inventor of kidney, waterfall, wiggly antennae on ants, and head and trunk. We can observe that all the signs of God Moore presents, are from nature, animals, and insects. Moore ends after each point of comparison by the statement "so who's the great inventor" influenced by "surah Rahman" which enlists the blessings of God and asks men not to forget them. 
This poem highlights Moore's emphasis on the spiritual relationship between human beings and nature, which stems from Moore's Sufi views. These views are a reflection of Nasr's ideas about the natural world as a reflection of the Divine. It is the result of Moore's and Nasr's interpretation of the Oneness of God, a principle which leads them to believe that everything is an expression of God's reality.

In addition, Nasr in his writings emphasis on the Islamicreligious view of nature. He contrasts the Islamic views of environment with the dominant secular views of the environment. There is a trouble in modern worldin discerning the environment because humans are unware of the spiritual significance of the environment.(Nasr, Encounter of Man and Nature 20)

Nasr diagnose of the environmental crisis in modern world as a direct cause of consumption and secular exploration of nature. On the one hand, consumption makes humans feel happy by gaining more things though asceticism becomes a crime.The desire of humans turns to needs of raw materials. These desires cause the destruction of nature because it is not controlled by any religious system. On the contrary, religion enables humans to control their desires and acquire the virtue of contentment. The virtue of contentment enables humans to live 
in harmony with nature. Nasr is calling for a balance between the inner desires and the outer environment. This is relating to what Nasr names "misdirecting of the yearning of the soul" which is the heart of the environmental crisis. (Religion and the order of Nature 272)

On the other hand, modern world is secular in exploration of nature characteristics. The acting and living in a secular way causes the destruction of the natural world and environment. Modern man tends to think of science that can help him to gain power and domination over his own affairs, without thinking of its ethical, environmental, and spiritual consequences. This leads to a belief known as 'scientism'.Tom Sorell, the professor of philosophy defines scientism as "The belief that science is the only valuable part of human learning." (1) Scientismis the development of a secular way of thinking about the natural environment. Nasr traces the environmental crisis to the desacralizing of nature that began in the world with 'scientism.'

Conversely, Sufism as the spiritual part of Islam creates an awareness of the spiritual importance of environment. It is a process that develops within the individual and affects on his actions. Thus, Nasr and Moore call for an internal change to the individual that will control his actions towards the planet. 
Sufism has the ability to help in solving the environmental crisis. It influences on the lives and thought of a large number of Muslims, so it has the opportunity to make Muslims partners in solving the environmental crisis. This depends on encouraging the apprehension of ecological views among Sufis. A successful effort requires identifying themes in Sufism that can contribute positively to Islamic environmentalism. This will establish an authentic term of ecoSufism. This term originated in Ahmed Afzaal's essay 'Sufism'.

Sufis as representatives of Islamic spirituality have a deep reverence for nature. Sufism affirms the attributes of earth such as purity and fertility. This is obvious in the literature of famous Sufi writers. Sufi poets and writers frequently refer to roses, trees, oceans, rivers and birds. The renowned $13^{\text {th }}$ century Sufi poet Rumi wrote spiritual poetry highlighting the connection between spirituality and nature.

Sufis believe that there is perfection in nature. A Sufi considers nature not as reflective of an ideal but as itself an ideal. He believes that God has given human beings what they need, yet human selfishness and greed have ruined all things. Human beings have lost the peace within and around them. The world which was beautiful has now become ugly and disturbing. 
From this point of view, Moore proves that human beings interference into the natural world results in destruction.

Moore writes two poems about the nuclear environmental crisis. He wrote these two poems in May 1986 during Chernobyl nuclear reactor explosion. During this period, the debates arose about the nuclear reactor explosion which destroyed humanity and environment together. The two poems attack humans' negative situation because they cannotdo anything to stop the crisis.

In "The Meltdown of World" Moore sees the disaster of nuclear reactor as the catastrophe that will end life on earth. The poem reveals the cruelty of human beings and the peacefulness of animals:

The meltdown of the world continues and its vapors mix above the earth to spell out: Shame!

Ferns in rainforests open up their curling fronds and tiny fan-wing'd creatures on our bathroom wall sit still in whatever contemplation such gnats contemplate as a giant rendezvous with destiny rolls to its conclusive encounter almost audible in these hills, almost visible as the famously predicted yellow cloud from the East 
that would be one of the signals of the end of time as we know it flows along.

And I continue -

as the creature walking across the bathroom mirror continuesfasting.

(Ramadan Sonnets 17)

The world is in a very dangerous situation after the nuclear reactor accident. The nuclear accident destroyed both the physical environment and people. The first word of the poem is 'the meltdown' which shows Moore's negative attitude towards nuclear explosion. Moore uses figurative language in the poem; such as personificationby giving human characteristics to inanimate objects and insects. The image ' vapors spell out shame' is a personification. He personifies vapors as a man condemning the nuclear pollution. He also personifies ferns in rainforests and tiny creatures as a human contemplating his end because of the disaster.Moore uses the unfamiliar image ' yellow cloud', as an expression of the grim view of the disaster and a sign of the nuclear pollution. Then, Moore follows that it may be a sign of the end of life. The poem 
consists of three sentences in two stanzas. It is meant to be read in one breath. The poet doesn't want his readers to pause as much as he can.

The nuclear energy is a renewable energy but it is a risk to humans and environment. Humans' greed and secular view of the environment lead them to make use of it. They feel that they are superior to nature. The Islamic religious view of nature removes this duality between humans and environment.

Consequently, the environmental crisis of the planet is the result of an internal dilemma within humans that creates a disrespectful view of environment. The protection of environment can be accomplished by rediscovering the connection nature has with God, and developing an awareness of sacred quality that nature is a reflection of the divine. The outcome of Nasr's views is to solve the environmental crisis through the revival of the spiritual understanding of nature. Instead of trying to dominate nature, man has to endeavour to attain harmony with nature.

In the poem 'We stand on earth like dazzled scarecrows' Moore bemoans humans'careless position tothe nuclear power disaster. The poem presents an apathetic picture of humans on earth.The poet declares: 
We stand on earth like dazzled scarecrows.

The sky's black birds all flash away.

We walk like doom through blasted corn-rows regretting we failed to see the day

when mother-planet would lie back gray, depleted of her nourishing sweets.

The free-reined mind of man can't play with power the way kids play in streets.

The warning-sign of truth repeats itself until we see or not.

Vision shows us and completes our deepest intuitions thought.

Nuclear activity, domain of subtle powers we can't contain in form, but give up to Divinity.

\section{(Ramadan Sonnets 69)}

In other words, reading the poem emphasizes the carless actions humans have in response to the nuclear disaster. The whole poem is a description of the miserable conditions of humanity on earth after the nuclear explosion.Humans are like dolls on earth. They can do nothing. They walk like death in the corrupted corn rows complaining of the despairing position of 
the planet. The solution in the final line is to return to God, which is the solution Nasr suggests to the environmental degradation.

The metaphorical language of the poem reveals the poor situation of humans on earth after the nuclear explosion. The sense of despair is evoked from the two similes "we stand on earth like dazzled scarecrows" and "We walk like doom". The poet compares humans in the similes to death. Furthermore, the poet rushes from one image to another image without giving explanations. The poet leaves two line spaces within the poem, because he wants his reader to pause and think of the meaning. The two line spaceswithin the poem denote what we do not know about the environment.

To conclude, this paper has attempted to analyze selected poems by the American Muslim Sufi poet Daniel Abdal-Hayy Moore, using the main concepts of ecocriticism.The study engages in poems that match the core idea of the research. These poems illustrate how ecocriticism might contribute in understanding nature and the ecological crisis from religious views.In Moore's poetry, environmental issues are given great importance. Moore fought for the preservation of the environment from the cruelty of modern civilization. By giving 
religious dimension tothe natural world's importance, Moore could attract humanity to preserve the environment.

In addition, this paper explores Seyyed Hossein Nasr's influences on Moore's thought regarding natural world and the diagnosis of environmental crisis. Nasrclaims that the ecological dilemma is the result of the spiritual sickness of the modern man. 


\section{Works Cited:}

Afzaal, Ahmed. "Sufism." Encyclopedia of Religion and Nature.Ed. Bron R.

Taylor. London: Thoemmes Continuum, 2005. 1604-1606. Print.

Cohen, Michael. "Blues in the Green: Ecocriticism under Critique" American

Society for Environmental History 9.1 (Jan 2004) 9:36. Print.

Gana, Nouri." Introduction: Race, Islam and the Task of Muslim and

Arab

American Writings". PMLA (2008): 1573-1580. Print.

Glotfelty Cheryll and Harold Fromm, eds. The Ecocriticism Reader: Landmarks in

Literary Ecology. Athens and London: University of Georgia Press, 1996.

Print.

---."Literary Studies in an Age of Environmental Crisis." The Ecocriticism Reader: Landmarks in Literary Ecology. Cheryl Glotfelty and Harold Fromm, eds. Athens: University of Georgia Press, 1996. Print.

Howarth, William." Some Principles of Ecocriticism" The Ecocriticism

Reader: 
Landmarks in Literary Ecology. Cheryl Glotfelty and Harold Fromm, eds.

Athens: University Georgia Press, 1996. 69- 91. Print.

Mattawa, Khaled." Writing Islam in Contemporary American Poetry: On Mohja

Kahf, Daniel Moore and Agha Shahid Ali." PMLA 123(2008): 1590:1595.

Print.

Meeker, Joseph. The Comedy of Survival: Studies in Literary Ecology. New York:

Scribner, 1974. Print.

Moore, Daniel Abdal-Hayy. Ramadan Sonnets. Philadelphia:

Ecstatic Exchange, 2005. Print.

---. Invention of the Wheel. Philadelphia: Ecstatic Exchange, 2010. Print.

Reuckert, William. "Literature and Ecology: an Experiment in Ecocriticism." The

Ecocriticism Reader: Landmarks in Literary Ecology. Cheryl Glotfelty and Harold Fromm, eds. Athens: University of Georgia Press, 
1996.

105-123.

Print.

Seyyed Hossein Nasr. The Encounter of Man and Nature: the Spiritual

crisis

of Modern Man. London: Allen \& Unwin, 1968. Print.

---. Religion and theOrder of Nature: the 1994 Cadbury Lectures at the

University of Birmingham. New York: Oxford University Press, 1996.

Print.

---. "Religion and the Environmental Crisis." The Essential Seyyed Hossein

Nasr. Ed. William Chittick. Indiana: World Wisdom Inc., 2007. 29-39. Print.

Sorell, Tom. Scientism:Philosophy and the Infatuation with Science. London:

Routledge, 1994. Print. 